\title{
Assessing the health of coastal marine ecosystems: A holistic approach based on sediment micro and meio-benthic measures
}

\author{
P. Vassallo ${ }^{\text {a,* }}$, M. Fabiano ${ }^{\text {a }}$, L. Vezzulli ${ }^{\text {a }}$, R. Sandulli ${ }^{\mathrm{b}}$, \\ J.C. Marques ${ }^{c}$, S.E. Jørgensen ${ }^{\mathrm{d}}$ \\ ${ }^{a}$ Dipartimento per lo Studio del Territorio e Delle Sue Risorse, University of Genoa, Corso Europa 26, 16132 Genova, Italy \\ ${ }^{\mathrm{b}}$ Dipartimento di Zoologia, University of Bari, Via Orabona 4, 70125 Bari, Italy \\ ${ }^{\mathrm{c}}$ IMAR (Institute of Marine Research), Department of Zoology, University of Coimbra, 3000 Coimbra, Portugal \\ ${ }^{\mathrm{d}}$ DFH, Environmental Chemistry, University Park 2, 2100 Copenhagen, Denmark
}

Received 8 July 2005; received in revised form 14 July 2005; accepted 19 July 2005

\begin{abstract}
We applied a thermodynamic and network analysis on the micro and meio-benthic community in a wide coastal area of the southern Adriatic Sea in order to assess ecosystem health and to identify useful descriptors of environmental quality. The analysis of the micro and meio-benthic system in terms of organic matter, bacteria, microphytobenthos and meiofauna reflected changes occurring in the trophic state of benthic ecosystems and provided a tool for comparison between different environments. The biopolymeric carbon load never reached very high concentrations. Within these trophic conditions, ascendency, exergy and specific exergy resulted strictly related to each other and an increase of all the goal functions was observed at increasing resource availability. The analysis of trophic efficiency was particularly sensitive to assess the environmental state in term of sustaining complex structure and resource exploitation. In particular, specific exergy, ascendency/capacity and Finn's cycling index showed lowest values in more anthropogenic areas and can be proposed as candidate indices for the health assessment of coastal ecosystems.
\end{abstract}

(C) 2005 Elsevier Ltd. All rights reserved.

Keywords: Thermodynamic analysis; Network analysis; Mediterranean Sea; Benthic system

\section{Introduction}

Quantitative assessment of energy-matter storage and flows in complex marine ecosystems has

\footnotetext{
* Corresponding author. Tel.: +39010 3538069; fax: +390103538140 .

E-mail address: vassallo@ fisica.unige.it (P. Vassallo).
}

important implications for the understanding of ecological processes and the prediction of ecosystem function in response to environmental and anthropogenic impacts (Gaedke, 1995).

Jørgensen (1992) suggested that a holistic or whole system approach is required to draw conclusions on ecosystems properties. Holistic studies of ecosystems attempt to describe the flows of energy and matter 
between the interdependent biotic and abiotic components in different ways: sometimes through the creation of a food web whose definition varies from relatively simplistic to fairly complicated descriptions (Baird and Ulanowicz, 1989) and sometimes through a study of the thermodynamic features of the ecosystems (Mejer and Jørgensen, 1979).

Among holistic indicators, biodiversity, exergy, specific exergy and ascendency are often applied in assessing environmental quality. Exergy and specific exergy are two thermodynamic oriented indicators derived from ecosystem theory (Jørgensen and Mejer, 1977, 1979; Christensen, 1994; Jørgensen, 1995, 2002; Xu et al., 1999). Through their application, it is possible to detect both quantitative and qualitative alterations in the ecosystems, such as biomass, species composition and ecosystem activity. They have therefore been employed to evaluate the ecosystem structure, its function and organization. Ascendency is a network oriented indicator and its ecological application was first proposed by Ulanowicz (1986). Ascendency was developed in a phenomenological fashion and it is assumed to be closely linked to ecosystem efficiency, maturity and development. Several studies have been carried out to investigate terrestrial and aquatic ecosystems using exergy and ascendency as ecological indicators of health (Christensen, 1995; Pérez-España and Arreguín-Sánchez, 1999a,b, 2001; Jørgensen, 1994, 2000; Marques et al., 1997, 2003; Fabiano et al., 2004; Patrício et al., 2004; Salas et al., 2005).

With regard to coastal marine ecosystems, Fabiano et al. (2004) proposed applying exergy, specific exergy and ascendency to assess ecosystem health based on sediment microbenthic measures. The rationale behind this approach is that an analysis of target sub-systems within the ecosystem as a whole may represent an efficient way to investigate specific topics of disturbance (e.g. organic enrichment) on which the selected systems are more sensitive.

The microbenthic loop is a major sub-system within the marine food chain and its role in affecting ecosystem functioning has raised an increasing interest since it was first described in 1980 (Azam et al., 1983). In addition, due to their small size and rapid turnover rates, micro and meio-benthic organisms respond promptly to changes in environmental constrains (Vezzulli et al., 2002; Boyd et al., 2000). The microbenthic loop encompasses organic matter, bacteria, microphytobenthos, protozoa and meiofauna and the state of its structure and dynamics has been recently proposed as a sensitive indicator of change occurring in the marine ecosystem (Lee et al., 2001; Dell'Anno et al., 2002).

In their preliminary study, Fabiano et al. (2004) suggested that some holistic indicators (ascendency and specific exergy) calculated within the microbenthic loop sub-system seem to be suitable to assess the health of coastal marine systems since they are sensitive to environmental changes and trophic states. Furthermore, they reflect both ecosystem function and organization.

Following this approach, we investigated the exergy and ascendency variations across a large coastal area along the southern Adriatic continental shelf between Italy and Albania, in order to evaluate the health of coastal marine ecosystems and to identify useful descriptors of the environmental quality state. Applying ascendency, it is possible to determine quantitatively whether a system has grown or shrunk, developed or regressed. Patterns of changes in the information variables can be used to identify processes that hitherto had been described only verbally (Ulanowicz, 2000). On the other hand, the application of exergy and specific exergy as ecological indicators, allows us to capture the state of the system, distinguishing between different scenarios of disturbance symptoms (see, for instance, Marques et al., 2003).

The process of trophic enrichment, for example, can be described in terms of thermodynamic or of network attributes as an increase in total exergy followed by any increase in the system's ascendency (due to a nutrient enrichment) resulting in a rise in total system throughput that more than compensates for a concomitant fall in the mutual information (Ulanowicz, 1986) and specific exergy (Fabiano et al., 2004). This particular combination of changes in variables allows to distinguish between examples of simple enrichment and cases of undesirable eutrophication.

\section{Material and methods}

The calculation of exergy, specific exergy and ascendency within the micro and meio-benthic loop was made by using sediment data on organic matter, bacteria, microphytobenthos and meiofauna collected 

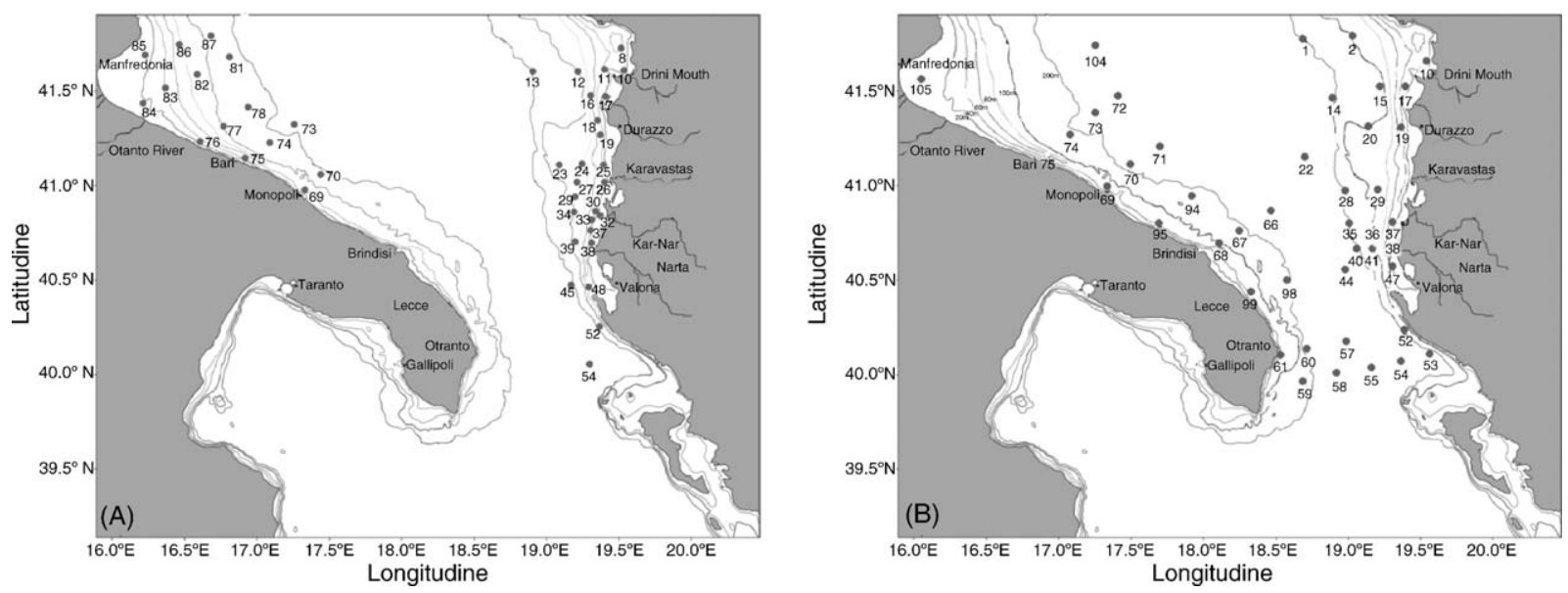

Fig. 1. Sampling stations in October (A) and April (B) cruises.

from 84 stations in the southern Adriatic Sea continental shelf. Two different coasts were sampled: the east coast of the Apulian peninsula in Italy and the Albanian coast between the Drini Mouth and the Vlore Gulf (Fig. 1).

The Italian and the Albanian coastal systems are characterised by different hydrological, physiographic and trophic conditions. The Italian continental shelf displays a steeper morphology with the 100 - $m$ isobath closer to the coastline if compared with the Albanian counterpart. The two shelves are separated by a deep region that reaches $1200 \mathrm{~m}$ depth in the middle of the basin. This contributes to the establishment of a coastal-offshore oligotrophic gradient as reported by classical measures of nutrients and productivity in the water column (Zavatarelli et al., 1998). Mean surface circulations in the area are well represented by the general circulation of the Adriatic Sea that consists of a cyclonic gyre with a northward flow along the eastern side and a southward return flow along the western side (Orlic et al., 1992; Artegiani et al., 1997a,b). During winter, the northward currents on the Albanian side are wider and more pronounced while in the summer, the southward currents along the Italian coast predominate (Zore, 1956; Buljan and Zore-Armanda, 1976). Several smaller circulation cells are embedded in this largescale gyre (Zore, 1956), such as the quasi-permanent cyclonic gyre around the southern Adriatic Pit between the two coasts.
The Apulian coast has been widely studied. Freshwater inputs are found only on the northern part (Cervaro, Carapella and Ofanto rivers) and anthropogenic pressure is of great relevance and well developed through intensive activities all along the coastline.

On the contrary, little information is available on the Albanian coast. This area extends for $477 \mathrm{~km}$ and displays a succession of river mouths and deltas, lagoon systems, marsh labyrinths and sandy beaches (Pano, 1984). The anthropogenic influences include the harbour outlets of four main cities (Leize, Durazzo, Lushnje and Valona), of seven main rivers (Drini, Mati, Ishmi, Erzeni, Shkumbini, Semani and Vjosa) and several coastal lagoons (Viluni, Ceke and Merxhani, Patok, Karavastas, Orikumi and Narta) exploited for economic activities such as fish farming, salt production and the harvesting of emergent plants (Peja et al., 1996).

Sampling campaigns were carried out during October 2000 and April-May 2001 on board of the 'R/V Italica (Napoli)'. The sampling plan for each cruise included 41 stations in October 2000 (Fig. 1A) and 43 stations in April-May 2001 (Fig. 1B). The sampling strategy included several transects or grouped stations. For each area or transect, an inshore-offshore gradient was identified and covered by the sampling schedules. Sediment samples were collected using a Van Veen grab. Three to five deployments per stations were carried out to obtain at 
Table 1

Benthic parameters and groups utilized for the calculation of exergy and ascendency within the microbenthic loop system

\begin{tabular}{lll}
\hline Benthic parameters & Groups & References \\
\hline Chlorophyll- $a$ & Microphytobenthos & Plante-Cuny (1974) \\
Bacteria biomass & Bacteria & Meyer-Reil (1983) \\
Nematodes & Wieser (1960), Warwick and Price (1979), Romeyn and Bowman (1983) \\
Copepods & Wieser (1960), Warwick and Price (1979) \\
Meiofauna & Polychaetes & Wieser (1960), Warwick and Price (1979) \\
& Turbellarians & Wieser (1960), Warwick and Price (1979) \\
Total organic matter & Others & Wieser (1960), Warwick and Price (1979) \\
\hline
\end{tabular}

least three independent replicate samples. Only the top $2 \mathrm{~cm}$ sediment layer was collected for chemical analysis and the top $5 \mathrm{~cm}$ sediment layer for the meiofauna analysis.

Sampling campaigns were carried out in two key seasons for the marine environment, during spring and autumn algal bloom when productivity and benthic pelagic coupling can provide the most significant response.

The benthic measures and groups used for the calculation of exergy and ascendency within the microbenthic loop system are reported in Table 1. Units of measure for each groups were standardized to $\mathrm{t} \mathrm{km}^{-2}=\mathrm{g} \mathrm{m}^{-2}$. Identification of meiofauna reaches the resolution needed to the application of the weighting factors for the calculation of exergy (Marques et al., 2003). The meiofauna components employed in the calculation were the most abundant in the samples: nematodes, polychaetes, copepods and turbellarians.

\subsection{Biochemical analyses}

Carbohydrates (CHO) were analysed according to Dubois et al. (1956): D(+) glucose solution was used as a standard. Protein (PRT) analyses were carried out following Hartree (1972), modified by Fabiano et al. (1995): albumin solution was used as standard. Lipids (LIP) were extracted according to Bligh and Dyer (1959) and measured following Marsh and Weinstein (1966): tripalmitine solution was used as standard. For each analysis, controls were performed following the same method, with sediment pre-treated in a muffle furnace $\left(550{ }^{\circ} \mathrm{C}, 4 \mathrm{~h}\right)$. The carbon biopolymeric fraction (BPC) was calculated according to Fabiano and Danovaro (1994) as the sum of lipids, proteins and carbohydrates converted to carbon equivalents according to Fichez (1991).

\subsection{Exergy}

The exergy index (Ex) was calculated as the concentration of different groups $X_{i}$ (in this case equivalent to biomass) multiplied by weighting factors $\beta_{i}$, based on the exergy detritus equivalent according to Marques et al. (2003) (Table 2). Exergy links the chemical energy of the various groups of the ecosystem to the information embodied in DNA as explained by the following equation:

$\mathrm{Ex}=\sum_{i} \beta_{i} \times X_{i}$

Table 2

Values of the "qualities" of the biomass expressed by the weighing factors used by Marques et al. (2003) and in this study (underlined values)

\begin{tabular}{|c|c|}
\hline Organisms & Weighing factors, $\beta$ \\
\hline Detritus & $\underline{1}$ \\
\hline Bacteria & $\underline{3}$ \\
\hline Algae & $\underline{3.9}$ \\
\hline$\overline{\text { Annelid }}$ & $\overline{50}$ \\
\hline Crustacean zooplankton & $30-46$ \\
\hline$\underline{\text { Nematodes }}$ & $\underline{50}$ \\
\hline Polychaetes & $\underline{50}$ \\
\hline Copepods & $\underline{30}$ \\
\hline Turbellarians & $\underline{50}$ \\
\hline Fish & $\overline{287}-344$ \\
\hline Birds & 1100 \\
\hline
\end{tabular}

The weighing factors values are based on the number of information genes. The exergy content of organic matter in the various organisms is compared with the exergy contained in detritus. 
where $\beta_{i}$ represent the weighting factors and $X_{i}$ are the concentrations (biomass) of each group in the system.

Unit exergy detritus equivalents are expressed in $\mathrm{g} \mathrm{m}^{-2}$ and can be converted to $\mathrm{kJ} \mathrm{m}^{-2}$ by a factor of 18.7 corresponding to the approximate average energy content of $1 \mathrm{~g}$ of detritus (Jørgensen, 2000).

A variation in exergy values could be due to variations of biomass or to variations of the structural complexity of the biomass.

$\partial \mathrm{Ex}=\sum_{i=1}^{n} \partial X_{i} \times \beta_{i}+X_{i} \times \partial \beta_{i}$

where the latter represents the information embedded in the DNA and could be called specific exergy or exergy per unit of biomass. Specific exergy is given by:

$\mathrm{Ex}_{\mathrm{sp}}=\frac{\mathrm{Ex}}{\sum_{i-1}^{n} X_{i}}$

\subsection{Network analysis}

- Total system throughput (TST) is the sum of all transfer processes occurring in the system and gauges the level of overall system activity: $T=$ $\mathrm{TST}=\sum_{i, j} T_{i j}$ for all possible transfers $T_{i j}$, where $i$ and $j$ represent either an arbitrary system component or the environment.

- Ascendency $(A)$ incorporates aspects of both a system's size and the degree of organization with which the material is being processed (Ulanowicz and Abarca-Arenas, 1997). For the computation of ascendancy, the following equation was used: $\mathrm{A}=T \times I=\sum_{i=1}^{n} \sum_{i=1}^{n} T_{i j} \log \left(T_{i j} B^{2} / B_{i} B_{j} T\right)$, where $k$ is constant, $T_{i j}$ the flux of biomass out of $i$ group and going in $j$ group, $T$ the sum of all the fluxes of biomass in the system and $B_{i}$ is the biomass of $i$ group.

- Development capacity $(C)$ represents the diversity of the system flows scaled by the total system throughput. Quantitatively, it is calculated as: $C=\sum_{i, j} T_{i j} \log \left(\frac{T_{i j}}{T}\right)$. It represents the upper level for the increase of ascendency.

- Average mutual information $(I)$ is the average constraint placed upon a single unit of flow in the network (Ulanowicz, 1986) and is calculated as the unscaled form of ascendency: $I=\sum_{i=1}^{n} \sum_{i=1}^{n}$
$\frac{T_{i j}}{T} \log \left(T_{i j} B^{2} / B_{i} B_{j} T\right)$. The average mutual information is able to measure the level of organization by with the exchanges among components of the system are transacted.

- Finn's cycling index (FCI) accounts for the percentage of all fluxes of biomass that is generated by cycling. FCI utilizes the Leontief matrix (Leontief, 1963) to assess the material cycling within the ecosystem by the application of this formula: $\mathrm{FCI}=\sum_{i=1}^{n} \frac{S_{i}}{\operatorname{TST}} \frac{l_{i i}-1}{l_{i i}}$, where $l_{i i}$ is the $i$ th coefficient along the Leontief matrix and $S_{i}$ is the inflow to the $i$ th group. For further information, the reader is referred, e.g. to Finn (1976) or Allesina and Ulanowicz (2004).

- Lindeman's trophic analysis interprets the network according to the trophic concepts of Lindeman (1942) by using the methods of interpretation developed by Ulanowicz (1986). In the Lindeman transformation matrix, the percentage pertaining to each trophic level is calculated as a ratio of biomass flows that involve organisms belonging to this trophic level in respect to total fluxes in the system. The Lindeman spine is a further derivation of the Lindeman trophic analysis and represents an abstract food chain derived by collapsing the network into a finite number of steps with the aim of displaying the relative contribution of each component of the food web to each trophic step (Field et al., 1989). This merges the detrital pool with the primary producers to represent the first trophic level, and indicates returns from all levels to the detrital pool as well as the amount of export and dispersion via respiration (Baird et al., 1991).

All the network indices involved in this study were calculated using the software Ecopath with Ecosim (Christensen et al., 2000).

\subsection{Basic modelling approach}

The models for each study area were created using the Ecopath 5.0 software which for each group (array of species with similar ecological attitude) uses a set of linear equations in order to balance the flows of biomass (in and out) of each compartment (Christensen et al., 2000).

For a basic parameterization, the model's routine uses a system of linear equations, which can be 
Table 3

Data of production, consumption and unassimilated food used in the simulations and respective literature sources

\begin{tabular}{lrll}
\hline Group & $P / B$ & $P / Q$ & $\mathrm{Un} / Q$ \\
\hline Microphytobenthos & $45^{\mathrm{a}}$ & $/ /$ & $/ /$ \\
Bacteria & $110^{\mathrm{b}}$ & $0.32^{\mathrm{b}}$ & $0.05^{\mathrm{c}}$ \\
Nematoda & $8^{\mathrm{d}}$ & $0.2^{\mathrm{d}}$ & $0.36^{\mathrm{c}}$ \\
Copepoda & $8^{\mathrm{d}}$ & $0.2^{\mathrm{d}}$ & $0.4^{\mathrm{c}}$ \\
Polychaeta & $8^{\mathrm{d}}$ & $0.2^{\mathrm{d}}$ & $0.35^{\mathrm{c}}$ \\
Turbellaria & $8^{\mathrm{d}}$ & $0.2^{\mathrm{d}}$ & $0.35^{\mathrm{c}}$ \\
\hline
\end{tabular}

${ }^{a}$ Source: Rybarczyk et al. (2003).

b Source: Carrer and Opitz (1999).

c Source: Heymans and Baird (1995).

d Source: Arreguín-Sánchez et al. (2002).

expressed for an arbitrary time period by:

$$
\begin{aligned}
B_{i} & \times\left(\frac{P}{B}\right)_{i} \times \mathrm{EE}_{i} \\
& =C_{i}+\sum_{j=1}^{n}\left[B_{j} \times\left(\frac{Q}{B}\right)_{j} \times \mathrm{DC}_{i j}\right]
\end{aligned}
$$

Consequently, the software needs five parameters for each group: biomass $(B)$, production/biomass ratio $(P /$ $B)$, consumption/biomass ratio $(Q / B)$, ecotrophic efficiency $(\mathrm{EE})$ and diet composition input $\left(\mathrm{DC}_{i j}\right)$. If one of these parameters is not available, it could be calculated knowing four further parameters: unassimilated/consumption (GS), net migration rate $(E)$, biomass accumulation (BA) and catch mortality $(Y)$.
In this study, the ecotrophic efficiency was always estimated considering $E, \mathrm{BA}$ and $Y$ null for each simulation. Data of biomass derived from sample measures while data of production, consumption, unassimilated food and the respective literature sources are reported in Table 3; the original diet matrix involved in the simulations is reported in Table 4.

The model compartments consisted of 10 different groups: 1 primary producer, 6 consumers and 3 nonliving groups (detritus compartments).

The software routine gives an error message if the model output is not realistic. In particular, it checks if the ecological efficiency is $<1.0$ for all compartments. If inconsistencies are detected, the $B$ values are adjusted within the confidence limits (standard deviation) given by the analysis. If further inconsistencies were detected, the diet matrix (Table 4) was slightly adjusted till the simulation procedure can perform.

\subsection{Statistical analysis}

Two-way analysis of variance (ANOVA) was used to investigate overall differences among continental shelves and sampling periods for each investigated variables. Factors in the analysis were 'Space (two levels, orthogonal, fixed)' and 'Time (two levels, orthogonal, random)'. A two-tailed $F$-test was used to assess whether the two 'main effects' were significant against the residuals. Prior to the analysis, the homogeneity of variance was assessed by Cochran's test and,

Table 4

\begin{tabular}{|c|c|c|c|c|c|c|}
\hline & \multicolumn{6}{|c|}{ Predators } \\
\hline & Batteri & Nematodi & Copepodi & Policheti & Turbellari & Altri \\
\hline \multicolumn{7}{|l|}{ Prey } \\
\hline Microfitobenthos & & 0.1 & 0.8 & & 0.1 & 0.1 \\
\hline Bacteria & & 0.2 & & 0.1 & 0.1 & 0.1 \\
\hline Nematodes & & 0.1 & & 0.1 & 0.1 & 0.1 \\
\hline Copepods & & 0.1 & & 0.1 & 0.1 & 0.1 \\
\hline Polychaetes & & & & 0.1 & 0.1 & 0.1 \\
\hline Turbellarians & & & & 0.1 & 0.1 & 0.1 \\
\hline Others & & & & 0.1 & 0.1 & 0.1 \\
\hline Proteins & 0.65 & 0.325 & 0.13 & 0.26 & 0.195 & 0.195 \\
\hline Carbohydrates & 0.1 & 0.05 & 0.02 & 0.04 & 0.03 & 0.03 \\
\hline Lipids & 0.25 & 0.125 & 0.05 & 0.1 & 0.075 & 0.075 \\
\hline
\end{tabular}

Original diet matrix for the Ecopath simulation of the micro and meiobenthic sub-system

Detritus percentage of assimilation was assumed in function of its biological availability analysed in Mediterranean conditions (Misic and Fabiano, 1996). 
when necessary, data were appropriately transformed. Logarithmic transformation has been employed for data presenting a skewed trend. All statistical tests and correlation analyses were made using the statistics toolbox, R12, of Matlab. In all cases, the significance level was fixed to $p<0.05$; a Bonferroni correction has been applied to the significance value to avoid interpretation errors when multiple comparisons have been performed $\left(N=2, p_{\text {corr }}<0.025\right)$.

\subsection{Graphical visualization}

Cartographic representations of the results were performed with a suitably developed Matlab routine. The interpolation method involved in the calculation was the inverse square distance applied considering a number of neighbors that varied from a minimum of 2 to a maximum of 15. Around each sampling station, the graphical representation has been enlarged for an arbitrary selected ray of about $40 \mathrm{~km}$.

\section{Results}

\subsection{Quantity and biochemical composition of sedimentary organic matter}

The total biopolymeric carbon content (BPC) of sedimentary organic matter (calculated as the sum of protein, carbohydrate and lipid concentrations) was characterised by a lack of significant temporal changes between the two studied periods (Table 5).

BPC concentrations displayed similar mean values in October and April (Tables 5 and 6) and it showed a general decrease with sediment depth and from the inshore to offshore gradient (Fig. 2). The highest concentrations were observed in the Italian coast (in shallow zones in front of Monopoli in October and near Brindisi in April) while the lowest occurred in Albanian stations (in deep station in front of Lushnje and Durazzo in October and April, respectively) (Table 6).

\subsection{Network analysis}

Ascendency displayed a clear temporal variability (Table 5) with values that resulted higher in April than in October, $T$-test, $p<0.001$. The spatial pattern showed differences between two coastal systems (Table 5) and assessed higher values in April on the Italian coast ( $T$-test, $p<0.02)$ while in October there was not a significant difference between the two coastal shelves. In the Italian coast, the higher ascendency values were calculated for the stations in front of Bari and Monopoli (sta 75 in October and sta 69 in April) and the lowest in the northern part of the Apulian coast (sta 78 in October and sta 104 in April) (Table 6). For the Albanian coast, the highest values were observed in October near the Karavastas lagoon (sta 30) and in April in front of the Drini mouth

Table 5

Results of two-way analysis of variance performed on indices involved in the study

\begin{tabular}{|c|c|c|c|c|c|c|}
\hline Index & Source & Sum of square & d.f. & Mean square & $F$ & Probability $>F$ \\
\hline \multirow[t]{2}{*}{$\mathrm{BPC}$} & Coast & 1.2845 & 1 & 1.2845 & 5.77 & 0.0186 \\
\hline & Season & 0.0082 & 1 & 0.0082 & 0.04 & 0.8483 \\
\hline \multirow[t]{2}{*}{ Ascendency } & Coast & 1.4577 & 1 & 1.4577 & 4.98 & 0.0248 \\
\hline & Season & 6.1759 & 1 & 6.1759 & 21.09 & $<0.0001$ \\
\hline \multirow[t]{2}{*}{$A / C$} & Coast & 0.00349 & 1 & 0.00349 & 1.63 & 0.2057 \\
\hline & Season & 0.02843 & 1 & 0.02843 & 13.24 & 0.0005 \\
\hline \multirow[t]{2}{*}{ FCI } & Coast & 0.0241 & 1 & 0.0241 & 0.19 & 0.6609 \\
\hline & Season & 0.0471 & 1 & 0.0471 & 0.38 & 0.5398 \\
\hline \multirow[t]{2}{*}{ Exergy } & Coast & 4.852 & 1 & 4.852 & 10.73 & 0.0016 \\
\hline & Season & 9.3879 & 1 & 9.3879 & 20.76 & $<0.0001$ \\
\hline \multirow[t]{2}{*}{ Specific exergy } & Coast & 1.1567 & 1 & 1.1567 & 3.71 & 0.0575 \\
\hline & Season & 7.9954 & 1 & 7.9954 & 25.67 & $<\mathbf{0 . 0 0 0 1}$ \\
\hline
\end{tabular}

Significant values are given in bold. 
Table 6

Ecosystem indices for the two areas and the two seasons

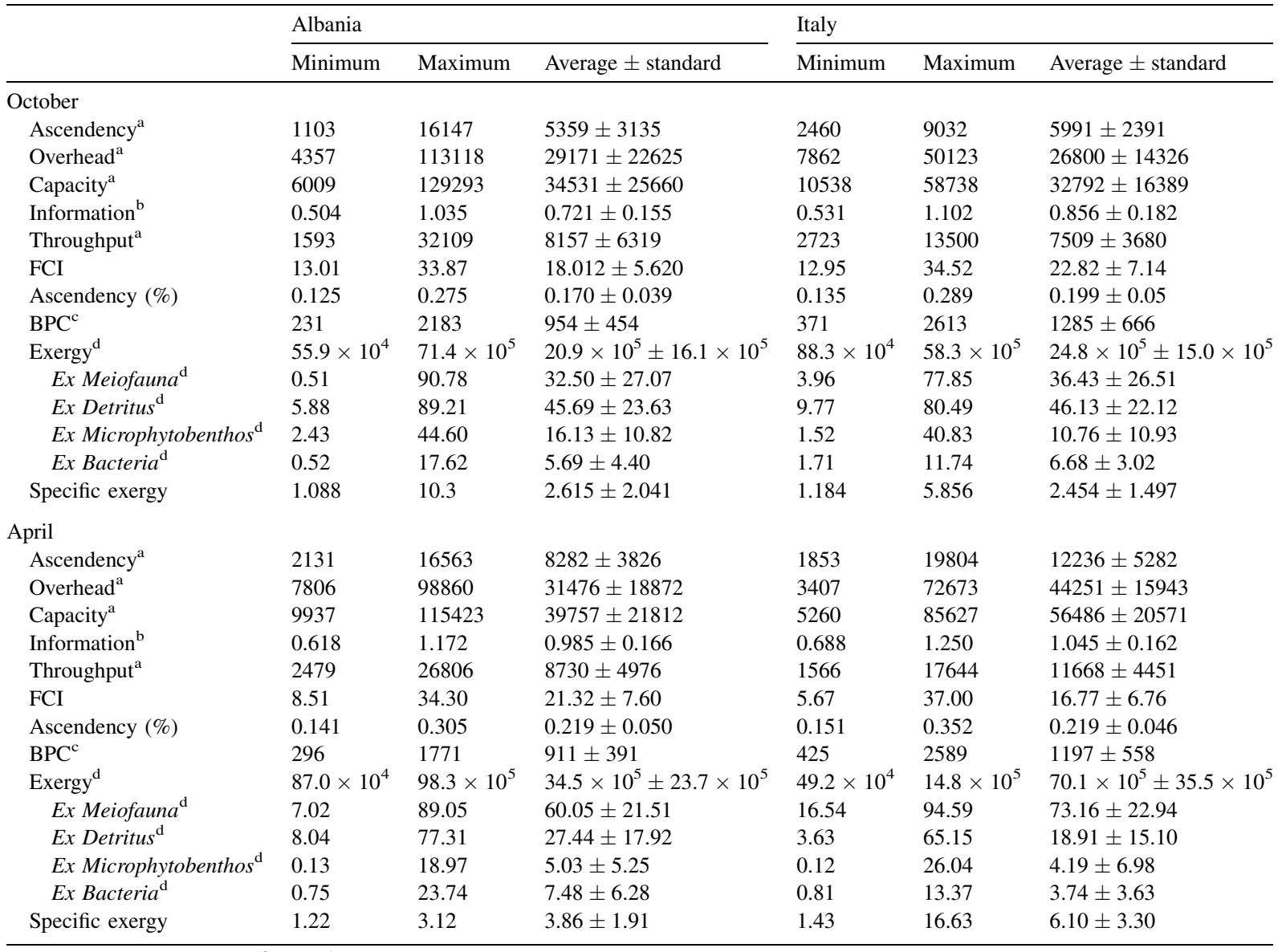

${ }^{\mathrm{a}}$ Unit of measure: $\mathrm{t} \mathrm{km}^{-2}$ year $^{-1}$.

${ }^{\mathrm{b}}$ Unit of measure: bit.

${ }^{c}$ Unit of measure: $\mathrm{t} \mathrm{km}^{-2}$.

${ }^{\mathrm{d}}$ Unit of measure: $\mathrm{kJ} \mathrm{m}^{-2}$.

(sta 10); the lowest values were detected in the southern part of the Albanian coast during both periods: in front of Otranto in October (south of the city of Valona; sta 52) and near the city of Valona in April (sta 40) (Table 6; Fig. 3).

Ascendency showed extremely high positive correlation values with throughput and capacity (Table 7) in both the sampling trips in accordance to its formulation and confirming the fact that the term TST is dominant in most calculations. A significant positive correlation was also found between ascendency and information in April-May (Table 7) while a negative correlation was observed in October (Table 7).

The relative ascendency $(A / C)$ is an important index for comparing different ecosystems since it excludes the influence of the total system throughput on ascendency and development capacity (Field et al., 1989). This ratio displayed higher values in April ( $T$ test, $p<0.001$ ) and they ranged in October between a minimum value near Lushnje (sta 30) and the maximum value near Bari (sta 76) and in AprilMay from minimum values in sta 37 at the south of Lushnje to maximum in the deep area in front of the 

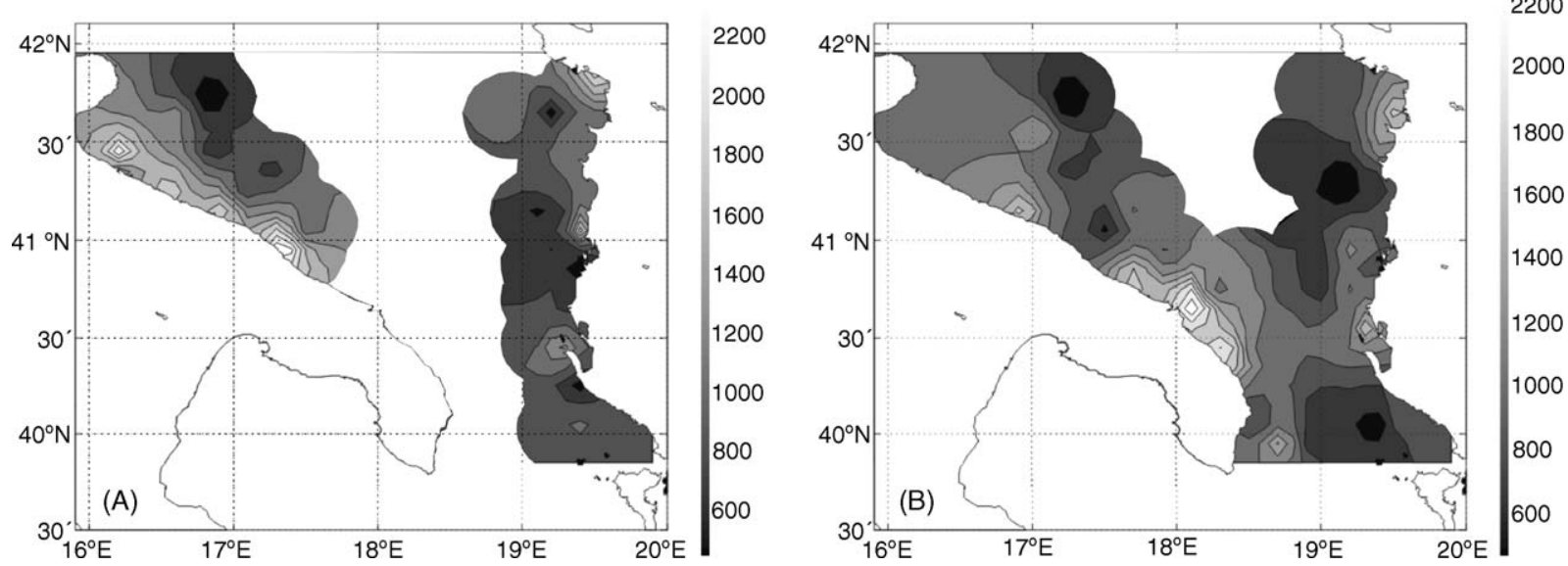

Fig. 2. BPC concentrations in: (A) October and (B) April. Reported values in $\mathrm{t} \mathrm{km}^{-2}$.

Ofanto river mouth off Bari (sta 104). The general spatial trend in April showed similar values in both the coasts while in October the Italian coast displayed the highest values ( $T$-test, $p<0.03)$. In both seasons, the Albanian coast displayed the highest values near the isoclines of $50 \mathrm{~m}$ : in April in the northern part of the coast while in October in front of the Drini mouth and Valona. For the Italian coast, the spatial trend was strictly dependent on the season and revealed that the highest values in April were in the deep zone (depth $>50 \mathrm{~m}$ ) in front to the Ofanto mouth while in October were displayed in the shallow zone in the north of the Apulian peninsula (Fig. 4).

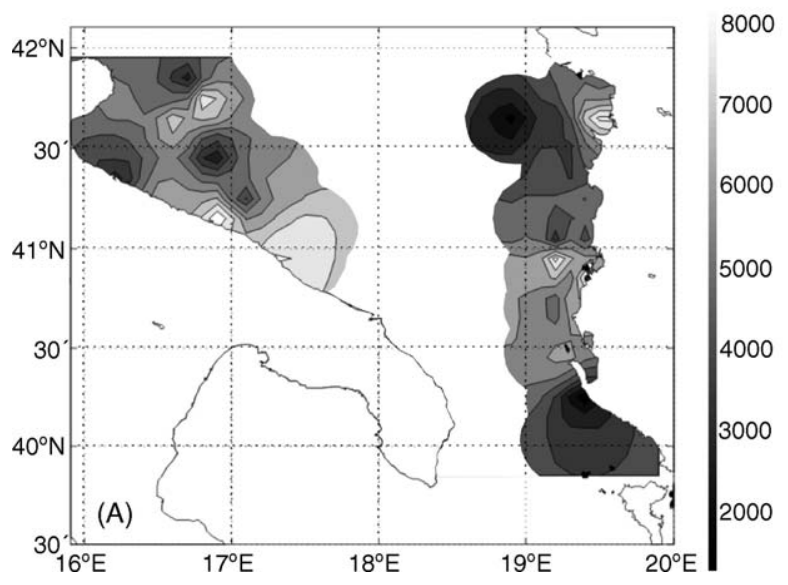

The Finn's cycling index, which is the fraction of total activity that is devoted to cycling (Finn, 1976), ranged in October from minimum values in the northern part of the Albanian coast (sta 10 near Ishmit river mouth) to a maximum reached in the shallowest area between Bari and Ofanto river (sta 76) (Table 6). In April-May, the lowest values were shown in front of Valona (sta 47) and the highest in the deep area off Bari (sta 104). The FCI values resulted both in April and in October strictly positively correlated with A/C (Table 7) and showed the same temporal and spatial trend (Fig. 5).

The Lindeman transformation matrix is based on knowledge of the dietary rations of all the compart-

Fig. 3. Ascendency values in: (A) October and (B) April. Reported values in $\mathrm{t} \mathrm{km}^{-2}$ year $^{-1}$. 
Table 7

Correlation index in October $(n=41, p>0.001, r=0.39)$ and in April $(n=43, p>0.001, r=0.38)$

\begin{tabular}{|c|c|c|c|c|c|c|c|c|c|}
\hline & Ascendency & Capacity & Information & Throughput & FCI & Ascendency $(\%)$ & BPC & Exergy & Specific exergy \\
\hline \multicolumn{10}{|l|}{ October } \\
\hline Ascendency & 1.00 & $0.94^{*}$ & -0.25 & $0.92^{*}$ & -0.23 & -0.29 & 0.11 & $0.52^{*}$ & 0.37 \\
\hline Capacity & & 1.00 & $-0.51^{*}$ & $0.99^{*}$ & -0.44 & $-0.53^{*}$ & -0.08 & 0.43 & 0.37 \\
\hline Information & & & 1.00 & $-0.54^{*}$ & 0.79* & $0.91^{*}$ & 0.31 & 0.08 & -0.01 \\
\hline Throughput & & & & 1.00 & -0.40 & $-0.51^{*}$ & -0.08 & 0.32 & 0.26 \\
\hline FCI & & & & & 1.00 & $0.94^{*}$ & 0.37 & -0.26 & -0.40 \\
\hline$A / C$ & & & & & & 1.00 & 0.36 & -0.16 & -0.28 \\
\hline $\mathrm{BPC}$ & & & & & & & 1.00 & 0.20 & -0.30 \\
\hline Exergy & & & & & & & & 1.00 & $0.82^{*}$ \\
\hline Specific exergy & & & & & & & & & 1.00 \\
\hline \multicolumn{10}{|l|}{ April } \\
\hline Ascendency & 1.00 & $0.86^{*}$ & 0.33 & $0.87^{*}$ & -0.25 & 0.16 & $0.54^{*}$ & $0.69^{*}$ & 0.43 \\
\hline Capacity & & 1.00 & -0.14 & $0.98^{*}$ & -0.47 & -0.29 & $0.59^{*}$ & $0.63^{*}$ & 0.35 \\
\hline Information & & & 1.00 & -0.15 & 0.28 & $0.84^{*}$ & -0.02 & 0.32 & 0.35 \\
\hline Throughput & & & & 1.00 & -0.33 & -0.20 & $0.56^{*}$ & $0.52 *$ & 0.24 \\
\hline FCI & & & & & 1.00 & $0.66^{*}$ & -0.34 & $-0.62^{*}$ & $-0.51^{*}$ \\
\hline$A / C$ & & & & & & 1.00 & -0.16 & -0.08 & -0.04 \\
\hline $\mathrm{BPC}$ & & & & & & & 1.00 & $0.49^{*}$ & -0.08 \\
\hline Exergy & & & & & & & & 1.00 & $0.80 *$ \\
\hline Specific exergy & & & & & & & & & 1.00 \\
\hline
\end{tabular}

Significant correlations are shown in bold.

* Significance level higher than $0.01 \%$.

ments in the ecosystem. For the application of the analysis, we have grouped the sampled stations in 12 averaged simulations: 6 of them in function of the BPC amount in the two sampling periods (in each sampling period, each simulation resulted from the average biomass calculated on five sampling stations that were closest to the lowest, highest and median value of BPC content, respectively) and the others in

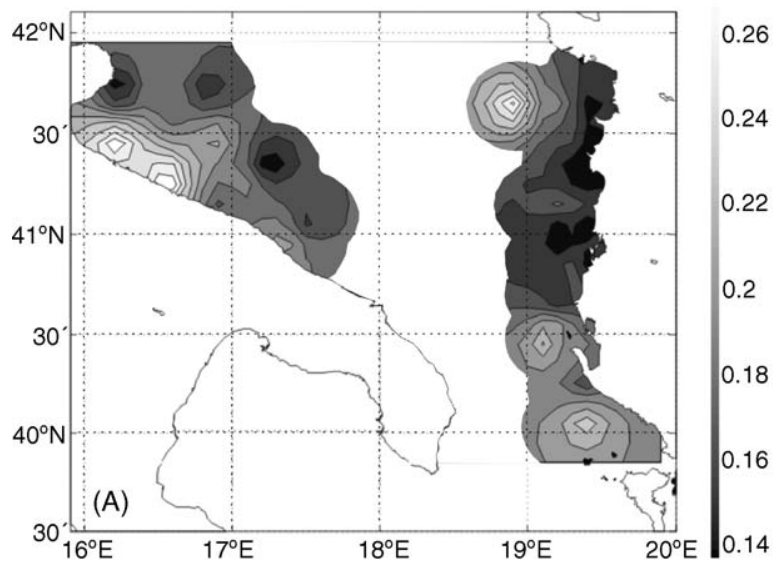

relation to the depth in the two coastal shelves (in this case, the simulations resulted from the average of all sampling stations included within the selected depth range). For each of these simulations, we identified six different trophic levels. All the groups in each simulations fed for the largest part in the first two trophic levels and if the sum of all groups is considered, the first trophic level contained at least

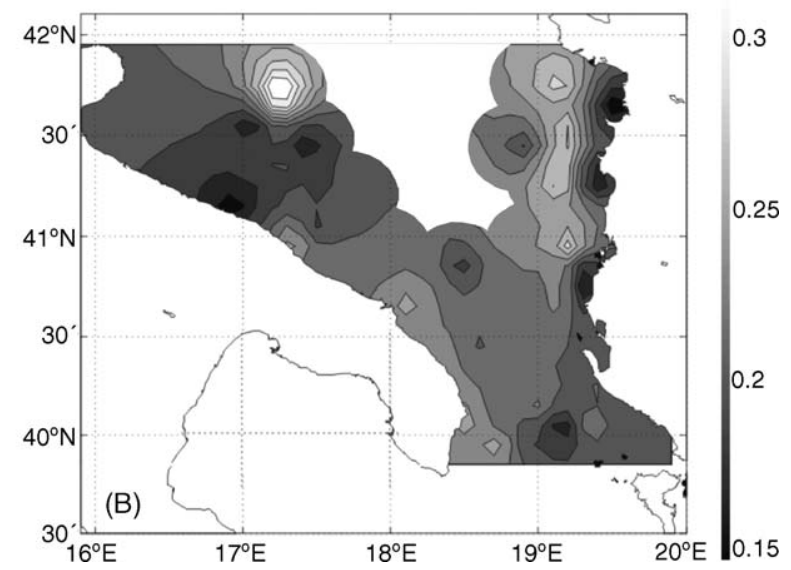

Fig. 4. Ascendency/capacity in: (A) October and (B) April. 

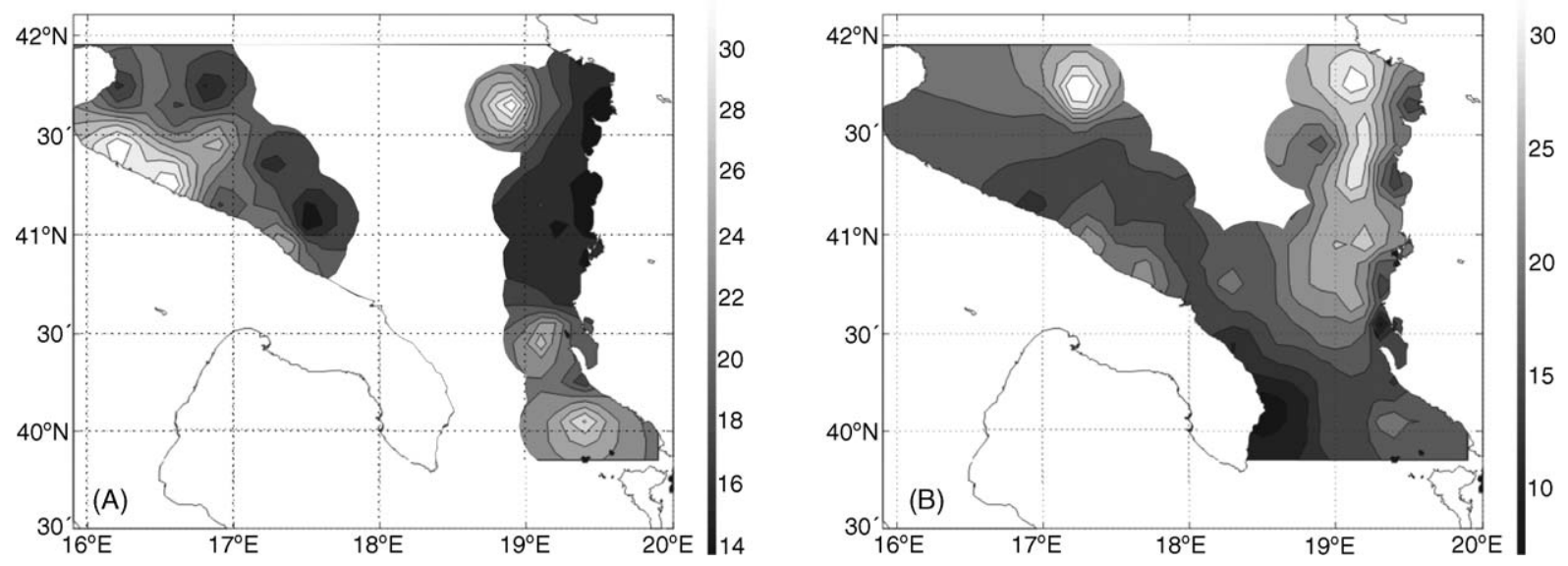

Fig. 5. FCI values in: (A) October and (B) April.

the $48 \%$ of total feeding activity and the second the $42 \%$ (Table 8). The trend of total activity with respect to the depth variation was the same in the two coastal shelves with a feeding activity on the first and second trophic level decreasing from the shallow to the deep stations. If variations of total activity in function of BPC concentrations were considered, a contrasting trend was detectable in the two seasons. A decrease of the total activity on the first two trophic levels at increasing BPC concentrations was observed in October while in April the station that most maintained feeding activity on the first level is the one with the highest BPC concentration.

A further derivation from the Lindeman trophic analysis is the construction of the Lindeman spine, an abstract food chain derived by collapsing the network into a finite number of steps which show the relative contributions of each component in the food web to each trophic step (Field et al., 1989). This merges the detrital pool with the primary producers to represent the first trophic level, and indicates returns from all levels to the detrital pool as well as the amount of export and dispersion via respiration (Baird et al., 1991). The Lindeman spines of the 12 systems considered (Fig. 6) had six compartments and only the first one showed a flux to the export. The trophic efficiency at the first level (trophic efficiency appearing inside the boxes in Fig. 6 is a measure of the fraction of input to a trophic level which is passed on to the next level) in both the coastal systems

Table 8

Cumulative percentage of the total activity on different trophic levels in 12 most significant simulations

\begin{tabular}{|c|c|c|c|c|c|c|}
\hline & TL I & TL II & TL III & TL IV & TL V & TL VI \\
\hline Albania_40 & 0.8365 & 0.9711 & 0.9981 & 1.0000 & 1.0000 & 1.0000 \\
\hline Italia_40 & 0.7180 & 0.9675 & 0.9983 & 1.0000 & 1.0000 & 1.0000 \\
\hline Albania_40_120 & 0.6652 & 0.9654 & 0.9976 & 1.0000 & 1.0000 & 1.0000 \\
\hline Italia_40_120 & 0.5936 & 0.9356 & 0.9970 & 1.0000 & 1.0000 & 1.0000 \\
\hline Albania_120 & 0.5581 & 0.9276 & 0.9958 & 0.9999 & 1.0000 & 1.0000 \\
\hline Italia_120 & 0.5324 & 0.9012 & 0.9948 & 0.9999 & 1.0000 & 1.0000 \\
\hline Min_April & 0.4881 & 0.9278 & 0.9961 & 0.9999 & 1.0000 & 1.0000 \\
\hline Med_April & 0.4838 & 0.9219 & 0.9938 & 0.9998 & 1.0000 & 1.0000 \\
\hline Max_April & 0.6688 & 0.9474 & 0.9969 & 0.9999 & 1.0000 & 1.0000 \\
\hline Min_October & 0.9129 & 0.9892 & 0.9994 & 1.0000 & 1.0000 & 1.0000 \\
\hline Med_October & 0.7977 & 0.9823 & 0.9986 & 1.0000 & 1.0000 & 1.0000 \\
\hline Max_October & 0.6660 & 0.9709 & 0.9980 & 1.0000 & 1.0000 & 1.0000 \\
\hline
\end{tabular}


followed a shallow-deep gradient with growing values at increasing depth indicating an increase in the direct utilization of detritus and producers products. The trophic efficiency related to BPC concentration showed that in April the microbenthic sub-system increases strongly its efficiency in resources exploitation at all trophic levels at increasing BPC while in October this trend is not detectable.

\section{Minimum April}

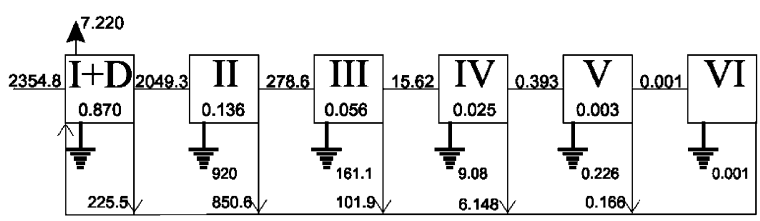

Median April

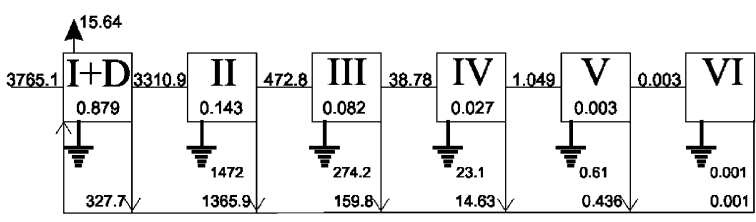

\section{Maximum April}

$\Lambda^{1025.24}$

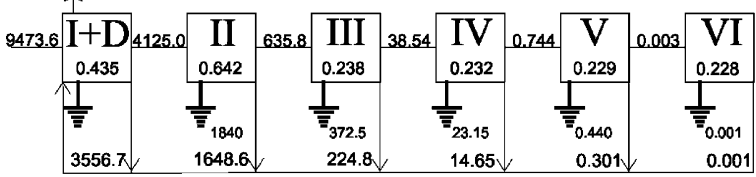

Minimum October

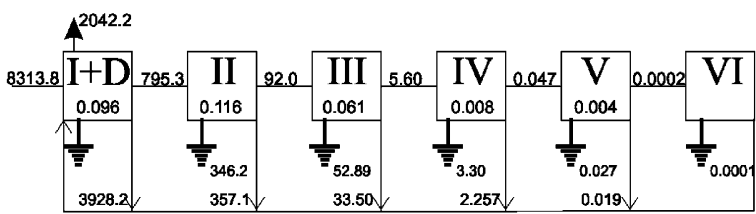

Median October

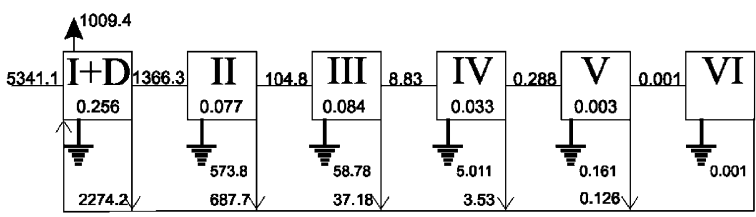

Maximum October

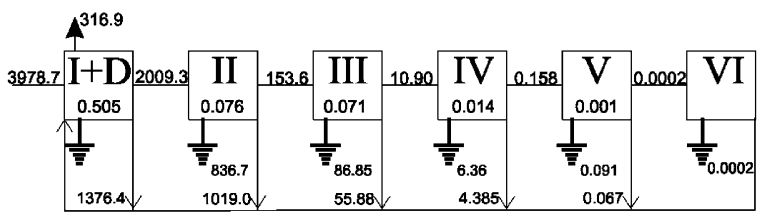

Albania_40

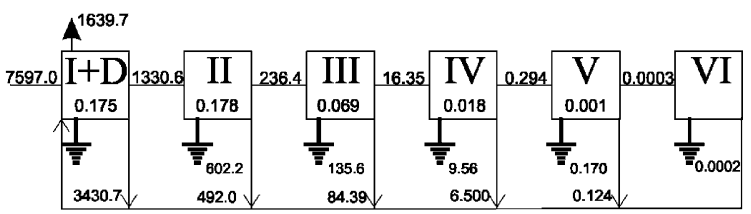

Italy_40

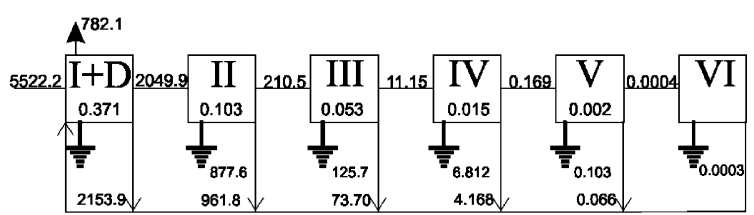

Albania_40_120

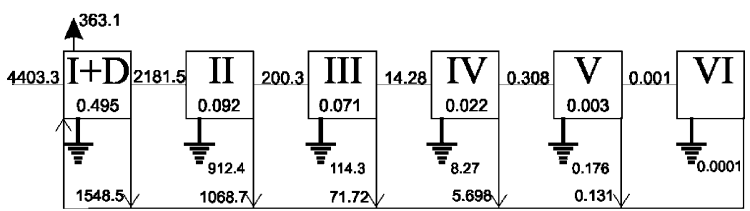

Italy_40_120

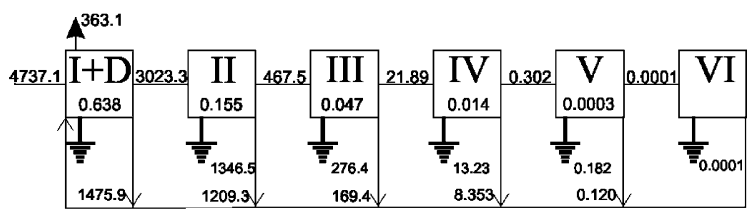

Albania_120

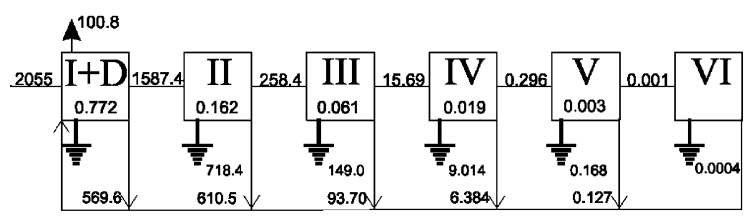

Italy_120

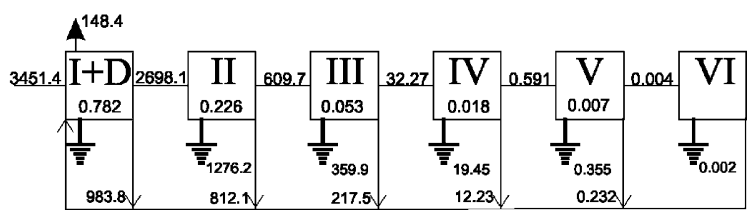

Fig. 6. Trophic aggregation into the Lindeman spine of the 12 selected simulations. 

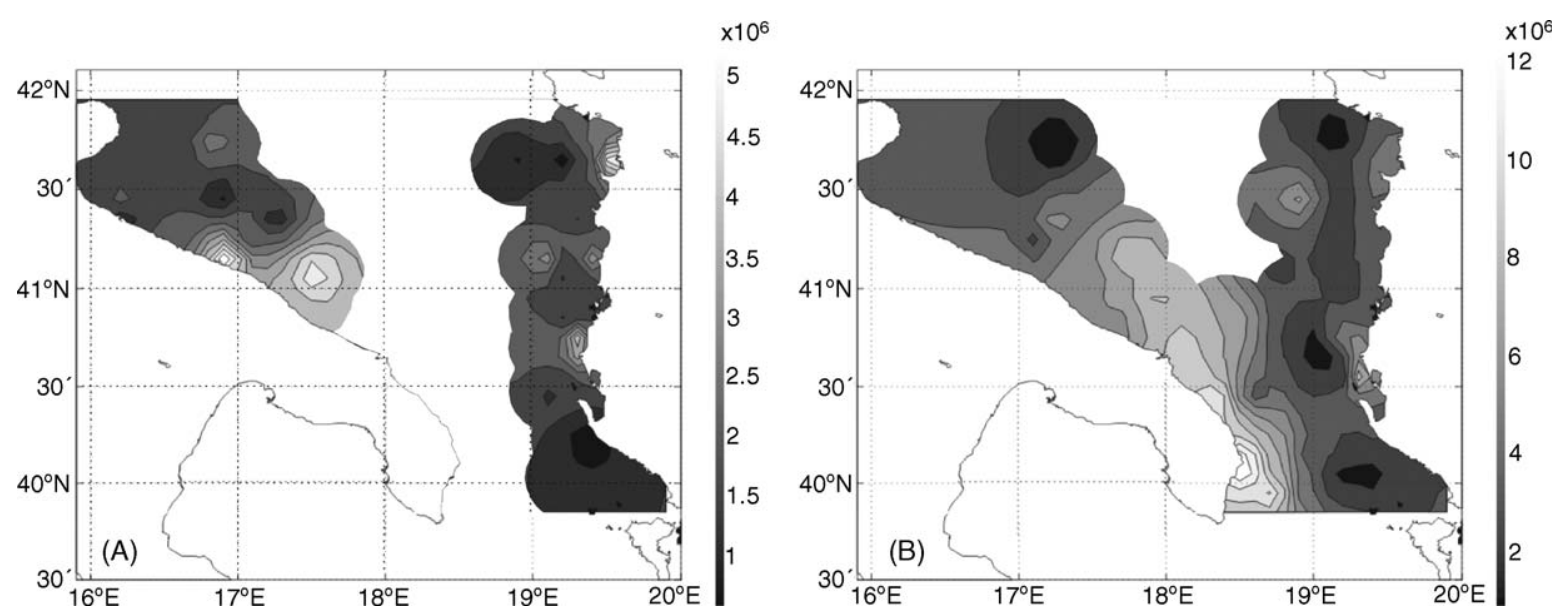

Fig. 7. Total exergy in: (A) October and (B) April. Reported values in $\mathrm{kJ} \mathrm{m}^{-2}$.

\subsection{Exergy}

Exergy values, calculated in accordance with the weighting factors reported in Table 2, in April ranged from minimum values detected off Bari (sta 104) to maximum in the southern part of the Apulian peninsula in the shallowest zone in front of Otranto (sta 61). In October, exergy displayed values from minimum in the southern part of the Albanian coast (sta 52) to maximum in the shallow area near Valona in front of the river Vjoses mouth (sta 38) (Fig. 7). An ANOVA test was performed to verify if significant differences existed between the two coasts and seasons (Table 5). Moreover, a $T$-test revealed that (as for the ascendency) in April, values are significantly higher than what observed in October (T-test, $p<0.01)$. The spatial trend did not show differences between the two seasons in Albania displaying the higher values in the shallow zone in front of the Drini mouth and in front of the city of Valona while in Italy there was a shift between April and October from the southern part of the peninsula (in front of the city of Otranto) to the coast in front of the cities of Bari and Brindisi. Exergy displayed a significant positive correlation with ascendency (Table 7) both in April and October.

The most important contributions to the total exergy values are from meiofauna and detritus
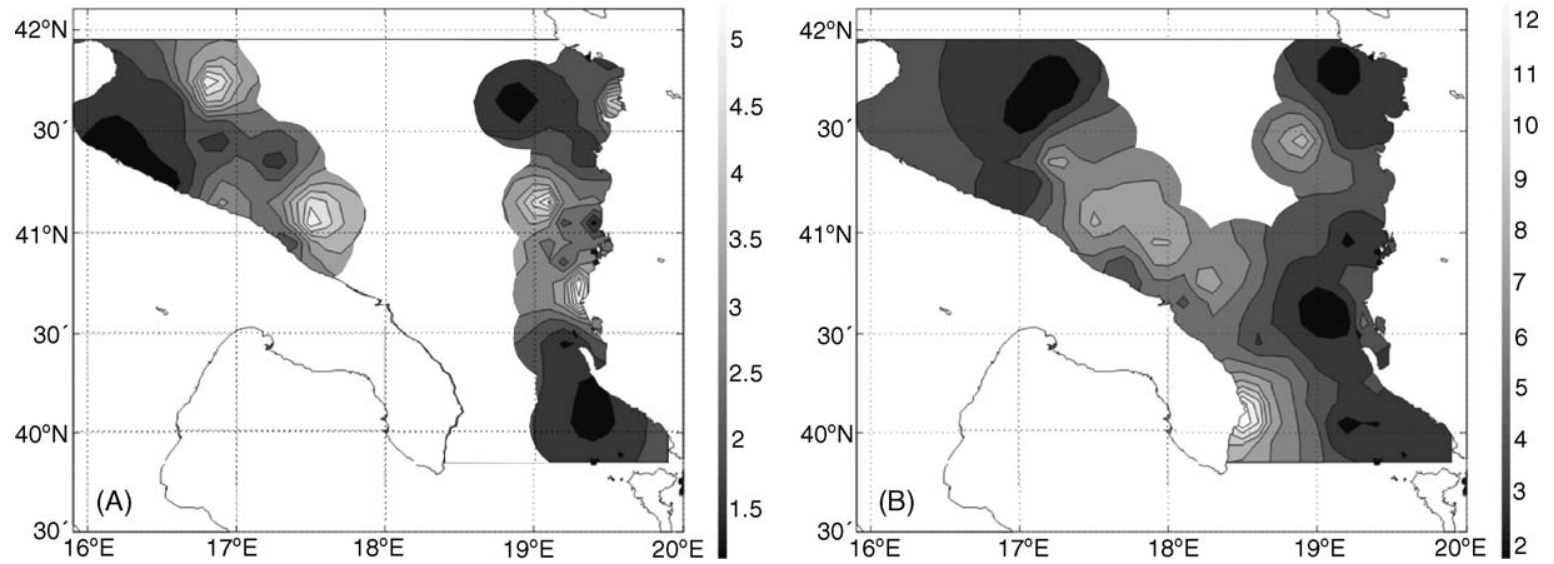

Fig. 8. Specific exergy in: (A) October and (B) April. 
compartments (Table 6). Specific exergy displayed both in April and in October high positive correlation values with exergy (Table 7). In April, the lowest specific exergy values are detected in the deep region off Valona (sta 40) and the highest in the southern part of the Apulian peninsula in the shallow area in front of Otranto (sta 61). In October, specific exergy ranged from what was observed off the river Ishmit mouth (sta 13) and what was detected in the shallow zone near Valona (sta 38). The ANOVA test revealed significant variations in respect of seasonality and values resulted significantly higher in April than in October ( $T$-test, $p<0.001)$. The spatial trend revealed the highest values in front of the city of Otranto in April and a general increase in the coastal zones in front of the southern part of the Apulian peninsula. Moreover, a general increase of the specific exergy values was detectable in the deeper zones between the two coastal systems. This latter behaviour was confirmed in October when, on the contrary, in front of Otranto, the spring peak was no more detectable and clear increases were shown in the shallow zones in front of the Drini mouth and off the city of Valona (Fig. 8).

\section{Discussion}

\subsection{Trophic state}

Biopolymeric carbon concentration in the sediment is the result of the processes occurring in the overlying water column (pelagic-benthic coupling) and gives an indication on the trophic state of coastal marine ecosystems (Dell'Anno et al., 2002). In our study, BPC concentration indicated that the two continental shelf systems displayed different trophic conditions (Fig. 2) with the highest values observed along the Italian coast. This was also shown in term of biopolymeric composition of sedimentary organic matter since an increase in protein and a decrease in carbohydrate contributions to total BPC was observed moving from the Albanian to the Italian coast (Fabiano et al., in press).

Following the classification proposed by Dell'Anno et al. (2002) on the base of protein and carbohydrates concentrations, the south Adriatic coastal system was generally considered as oligotrophic or meso-oligotrophic with the exception of few stations at shallow depth along the Italian continental shelf (Manfredonia, Ofanto, Barletta, Bari, Brindisi and Otranto). The Italian coast is in fact far more urbanised than the Albanian counterpart and this can explain the differences in organic matter concentrations and biochemical composition at shallow depth. At greater depth and along the Albanian coast, BPC concentrations resulted generally low if compared with values observed in other coastal ecosystems (Fabiano et al., 2004) in the Mediterranean Sea and comparable with natural or, more generally, nonstressed systems.

\subsection{Thermodynamic features}

Exergy displayed a spatial pattern similar to those described for BPC with the highest values observed near the coasts were nutrient availability and trophic conditions allow the system to develop its structure (i.e. biomass) and complexity (embodied information). Both in Italian and Albanian shelves, the highest coastal exergy values were identified in proximity of the major cities or near the outlet of the main rivers. This lets us suppose a relationship between allocthonous and anthropogenic input, high resource availability and embodied energy within the microbenthic loop sub-system. In confirmation of this attitude, the correlation between exergy and BPC is positive in both in April and in October (even if not significant) (Table 7). This latter trend could be related to the presence of freshly produced material in spring supporting the development of a more complex trophic structure (Fig. 6) within the microbenthic sub-system. This is also confirmed by the positive correlation (Table 7) observed between exergy and the protein content (describing the quality of organic matter) and between the total activity on the first trophic levels and BPC (Table 8). In contrast, the lower correlation values observed in October most probably depended upon the presence of more refractory organic matter and consequently to a minor efficiency of resource exploitation within the microbenthic subsystem (Table 8).

Similar considerations can be inferred if specific exergy is considered. In fact, the highest specific exergy values are detected in April (Table 6; Fig. 8) confirming that the system showed a greater complexity during the productive season justifying also the 
shift of trophic activity to the higher trophic level (Table 8).

Generally, exergy and specific exergy showed a positive correlation within the investigated stations (Table 7) in contrast to what observed in the same subsystem but in more trophic areas (Fabiano et al., 2004). This trend is always respected in the studied areas with the exceptions of shallow Italian and deeper oligotrophic stations where the two indices showed an opposite behaviour. In particular, the coastal areas between Bari and Otranto (the highest human impacted zone) displayed the highest exergy but low specific exergy values. This suggests that differences between exergy and specific exergy in these areas were mostly due to the increase in biomass (i.e. detritus biomass) rather than biological complexity or abundance of high trophic level organisms. On the contrary, in oligotrophic stations, an opposite relationship was detectable and higher specific exergy are coupled to lower exergy values. This can be explained by the ability of the microbenthic loop sub-systems to sustain a complex biological structure (greater efficiency) where the natural resources are lower (oligotrophic). This attitude is confirmed also by the comparison with data obtained from other studies on the microbenthic loop subsystems examining natural systems with higher trophic load. In fact exergy values resulted comparable (slightly higher) with those observed in previous studies in the microbenthic loop sub-system of coastal ecosystems in the north-western part of Mediterranean Sea (average $7.69 \times 10^{5} \pm 5.66 \times$ $10^{5} \mathrm{~kJ} \mathrm{~m}^{-2}$ ) (Fabiano et al., 2004) while, on the contrary, specific exergy resulted strongly higher in respect to what was observed in the same sub-system in coastal zones (average $1.190 \pm 0.163$ ).

\subsection{Network analysis variations}

The ascendency values calculated in the southern Adriatic Sea showed a different spatial pattern between the southern part of the Italian coast (south of Bari) and the Albanian and northern Italian coasts, with significantly lower values found in the latter. An exception to this trend was observed at the Drini Mouth and from Karavastas to Valona in October.

Along the Albanian coast, ascendency displayed peaks of values in coastal stations close to the rivers' outlets, namely in October when this behaviour was emphasized by the increased river input due to more frequent raining events. On the other hand, in the Italian coast, higher ascendency values appeared to be related to the presence of human and industrial activities that are mainly focused in the southern part of the Apulian peninsula. Even if increases in ascendency are generally reported to be related to an increase in maturity of the systems (e.g. Patrício et al., 2004; Christensen, 1995; Ulanowicz and Abarca-Arenas, 1997), previous observations on the micro and meio-benthic sub-system (Fabiano et al., 2004) characterised the increase in ascendency as a function of an increase in the microbenthic loop subsystem activity, devoted first to the assimilation and later to the dissipation of the increased organic matter and nutrients in the system. This is confirmed, in this case, considering values of $A / C$ and of FCI that displayed different spatial trends in respect of the ascendency values. This is mostly derived from an inverse relationship with TST (Table 7) indicating that when the overall activity increases, the system displays a decrease in its efficiency in resource exploitation. On the base of these findings, the most efficient trophic networks and the most complex cycling structures were found in deeper and more oligotrophic areas and in shallow areas characterised by lower organic loads and lower anthropogenic pressure. In contrast, in more anthropogenic areas, the micro and meio-benthic loop sub-system showed clear dissipative behaviour with highly active networks but low efficiency of resources exploitation.

\section{Conclusion}

Thermodynamic and network analyses have been widely employed in many previous studies for the health assessment of ecosystems. In fact, exergy is assumed to become optimized during ecosystem development and ecosystems are supposed to selforganize toward a state of an optimal configuration of this property. Exergy may then constitute a good ecological indicator of ecosystem health (Marques et al., 1997). Moreover, ascendency as defined by Ulanowicz (1986) quantifies both the level of system activity and the degree of organization whereby it processes in autocatalytic fashion. Following this interpretation, ascendency has been involved in the 
determination of the level of maturity of the ecosystem (Christensen, 1995) because it has been considered strictly related to the 24 Odum's (1969) attributes of ecosystem maturity; moreover, exergy and ascendency displayed a similar growing trend in systems that are evolving trough an evolutionary process (Jørgensen, 1994, 2002; Christensen, 1995). Previous studies applied these kinds of analysis to a wide variety of ecosystems but in many cases the expected evolutionary trend was not followed by the analysed system in particular if the considered system is affected by disturbance and deviates from its healthy state. Marques et al. (1997) detected that exergy and specific exergy respond differently to ecosystem dynamics during an eutrophication process and they suggested that it could be advisable to use both indicators complementary. Ulanowicz (1986) asserted that the process of eutrophication can be described in terms of network attributes as any increase in ascendency that causes a rise in total system throughput that more than compensates for a concomitant fall in the mutual information. Fabiano et al. (2004) investigating in this direction proposed that the health of coastal benthic ecosystem can be detected from the comparative analysis of specific exergy and ascendency. In particular, uncoupling phenomena between these two indices within the microbenthic loop sub-system have been observed when a threshold level of organic matter concentration is reached overtaking the buffer capacity of the system (the "ecosystem fever" identified by Fabiano et al., 2004). In the southern Adriatic coastal shelf, this threshold level is never reached. This is confirmed by the variations of exergy and ascendency that displayed a continuous increase in absolute values at increasing BPC concentrations. From a general point of view, this trend is referred to systems that are evolving toward a maturity and more developed state. Concomitant increases of exergy and ascendency have been detected in many studies (Salomonsen, 1992; Christensen, 1992; Jørgensen, 1993) referred to unstressed systems examined during evolutionary processes. As a consequence, the ecosystem is supposed to be under its buffer capacity within the range of OM concentration detected and seems to react at increasing nutrient availability with a tendency to development. Nevertheless, different behaviours and reactions to the organic enrichment are detectable in the sense of a change in holistic indicators. The thermodynamic based indicators showed that the microbenthic loop sub-system displayed a greater ability to sustain complex biological structures (greater specific exergy identifies greater system efficiency) when natural resource concentration is low (oligotrophic). In contrast, in meso-eutrophic areas, specific exergy revealed significant depletion, which emphasizes that the increase in exergy is solely due to an increase in biomass and not in complexity. The network oriented indicators showed that the activity of the microbenthic loop sub-system at increasing BPC is devoted first to the assimilation and later to the dissipation of the increased organic matter and nutrients in the system confirming a decrease in efficiency of exploitation at increasing resources availability.

A strong correlation was observed between $A / C$ and FCI measuring the efficiency of the investigated system in term of sustaining complex structure and resource exploitation. These indices displayed a decrease in areas characterised by a stronger anthropogenic impact (i.e. shallow Italian stations) probably depending upon the origin and biochemical composition of the organic matter. This is an interesting finding and needs future investigations, since $A / C$ and FCI might be considered as candidate indices for the assessment of health when an ecosystem is far below the buffering capacity.

It appears reasonable to conclude that the combination of thermodynamic and network oriented indicators may provide a powerful tool for the health assessment of coastal marine ecosystems.

\section{References}

Allesina, S., Ulanowicz, R.E., 2004. Cycling in ecological networks: Finn's index revisited. Comput. Biol. Chem. 28, 227-233.

Arreguín-Sánchez, F., Arcos, E., Chávez, E.A., 2002. Flows of biomass and structure in an exploited benthic ecosystem in the Gulf of California, Mexico. Ecol. Model. 156, 167-183.

Artegiani, A., Bregant, D., Paschini, E., Pinardi, N., Raicich, F., Russo, A., 1997a. The Adriatic Sea general circulation, Part I: air-sea interactions and water mass structure. J. Phys. Oceanogr. 27, 1492-1514.

Artegiani, A., Bregant, D., Paschini, E., Pinardi, N., Raicich, F., Russo, A., 1997b. The Adriatic Sea general circulation, Part II: baroclinic circulation structure. J. Phys. Oceanogr. 27, 15151532. 
Azam, F., Fenchel, T., Field, J.G., Gray, J.S., Meyer-Reil, L.A., Thingstad, F., 1983. The ecological role of water column microbes in the sea. Mar. Ecol. Prog. Ser. 10, 257-263.

Baird, D., Ulanowicz, R.E., 1989. The seasonal dynamic of the Chesapeake Bay ecosystem. Ecol. Monogr. 59, 329-364.

Baird, D., McGlade, J.M., Ulanowicz, R.E., 1991. The comparative ecology of six marine ecosystems. Philos. Trans. R. Soc. Lond. $333,15-29$.

Bligh, E.G., Dyer, W.J., 1959. A rapid method of total lipid extraction and purification. Can. J. Biochem. Physiol. 37, 911-917.

Boyd, S.E., Rees, H.L., Richardson, C.A., 2000. Nematodes as sensitive indicators of change at dredged material disposal sites. Estuarine Coastal Shelf Sci. 51, 805-819.

Buljan, M., Zore-Armanda, M., 1976. Oceanographical properties of the Adriatic Sea. Oceanogr. Mar. Biol. Annu. Rev. 14, 11-98.

Carrer, S., Opitz, S., 1999. Trophic network model of a shallow water area in the northern part of the lagoon of Venice. Ecol. Model. 124, 193-219.

Christensen, V., 1994. On the behaviour of some proposed goal function for ecosystem development. Ecol. Model. 75/76, 3749.

Christensen, V., 1995. Ecosystem maturity-toward quantification. Ecol. Model. 77, 3-32.

Christensen, V., Walters, C.J., Pauly, D., 2000. Ecopath with Ecosim Version 4, Help System ${ }^{\circ}$. University of British Columbia, Fisheries Centre, Vancouver, Canada and ICLARM, Penang, Malaysia.

Dell'Anno, A., Mei, M.L., Pusceddu, A., Danovaro, R., 2002. Assessing the trophic state and eutrophication of coastal marine systems: a new approach based on the biochemical composition of sediment organic matter. Mar. Pollut. Bull. 44, 611-622.

Dubois, M., Gilles, K.A., Hamilton, J.K., Rebers, P.A., Smith, F., 1956. Colorimetric method for determination of sugars and related substances. Anal. Chem. 28, 350-356.

Fabiano, M., Danovaro, R., 1994. Enzymatic activity, bacterial distribution, and organic matter composition in sediments of the Ross Sea (Antarctica). Appl. Environ. Microbiol. 64, 38383845 .

Fabiano, M., Danovaro, R., Fraschetti, S., 1995. A three-year time series of elemental and biochemical composition of organic matter in subtidal sandy sediments of the Ligurian Sea (northwestern Mediterranean). Continental Shelf Res. 15, 14531469.

Fabiano, M., Vassallo, P., Vezzulli, L., Salvo, V.S., Marques, J.C., 2004. Temporal and spatial change of exergy and ascendency in different benthic marine ecosystems. Energy 29, 1697-1712.

Fabiano, M., Vezzulli, L., Misic, C. Sediment biochemical and microbial parameters for the evaluation of trophic status along the Italian and Albanian continental shelves. J. Sea Res., in press.

Fichez, R., 1991. Composition and fate of organic matter in submarine cave sediments; implications for the biogeochemical cycle of organic carbon. Oceanol. Acta 14, 369-377.

Field, J.G., Wulff, F., Mann, K.H., 1989. The need to analyse ecological networks. In: Wulff, F., Field, J.G., Mann, K.H. (Eds.), Network Analysis in Marine Ecology: Methods and
Applications. Coastal and Estuarine Studies. Springer-Verlag, Berlin, pp. 3-12.

Finn, J.T., 1976. Measures of ecosystem structure and function derived from analysis of flows. J. Theor. Biol. 56, 363-380.

Gaedke, U., 1995. A comparison of whole-community and ecosystem approaches (biomasses and distributions, food web analysis, network analysis, simulation models) to study the structure, function and regulation of pelagic food webs. J. Plankton Res. 6, 1273-1305.

Hartree, E.F., 1972. Determination of protein: a modification of the Lowry method that gives a linier photometric response. Anal. Biochem. 48, 422-427.

Heymans, J.J., Baird, D., 1995. Energy flows in the Kromme estuarine ecosystem, St. Francis Bay, South Africa. Estuarine Coastal Shelf Sci. 41, 39-59.

Jørgensen, S.E., 1992. Exergy and ecology. Ecol. Model. 63, 185214.

Jørgensen, S.E., 1993. Model-theoretical aspects of ecological modelling. Ecol. Model. 68, viii.

Jørgensen, S.E., 1994. Review and comparison of goal functions in systems ecology. Vie le Milieu 44 (1), 11-20.

Jørgensen, S.E., 1995. The application of ecological indicators to assess the ecological condition of a lake. Lakes Reservoirs: Res. Manage. 1, 177-182.

Jørgensen, S.E., 2000. Application of exergy and specific exergy as ecological indicators of coastal areas. Aquat. Ecosyst. Health Manage. 3, 419-430.

Jørgensen, S.E., 2002. Integration of Ecosystem Theories: A Pattern, third ed. Kluwer.

Jørgensen, S.E., Mejer, H., 1977. Ecological buffer capacity. Ecol. Model. 3, 39-61.

Jørgensen, S.E., Mejer, H., 1979. A holistic approach to ecological modeling. Ecol. Model. 7, 169-189.

Lee, M.R., Correa, J.A., Castilla, J.C., 2001. An assessment of the potential use of the nematode to copepod ratio in the monitoring of metals pollution. The Chañaral case. Mar. Pollut. Bull. 42, 696-701.

Leontief, W., 1963. The Structure of American Economy 19191939. Oxford University Press, New York.

Lindeman, R.L., 1942. The trophic-dynamic aspect of ecology. Ecology 23, 339-418.

Marques, J.C., Pardal, M.A., Nielsen, S.N., Jørgensen, S.E., 1997. Analysis of the properties of exergy and biodiversity along an estuarine gradient of eutrophication. Ecol. Model. 102, 155-167.

Marques, J.C., Nielsen, S.N., Pardal, M.A., Jørgensen, S.E., 2003. Impact of eutrophication and river management within a framework of ecosystem theories. Ecol. Model. 166 (1-2), 147-168.

Marsh, J., Weinstein, D., 1966. Simple charring method for determination of lipids. J. Lipid Res. 7, 574-576.

Mejer, H.F., Jørgensen, S.E., 1979. Energy and ecological buffer capacity. In: Jørgensen, S.E. (Ed.), State of the Art of Ecological Modelling. Environmental Sciences and Applications, Proceedings of the 7th Conference on Ecological Modelling, 28 August2 September 1978, Copenhagen. International Society for Ecological Modelling, Copenhagen, pp. 829-846.

Meyer-Reil, L.A., 1983. Benthic responses to sedimentation events during autumn to spring at a shallow water station in the western 
Kiel Bight. II. Analysis of benthic bacterial populations. Mar. Biol. 77, 247-256.

Misic, C., Fabiano, M., 1996. A functional approach to the assessment of the nutritional value of particulate organic matter. Chem. Ecol. 13, 51-63.

Odum, E.P., 1969. The strategy of ecosystem development. Science $164,262-270$

Orlic, M., Gai, M., La Violette, P., 1992. The currents and circulation of the Adriatic Sea. Oceanol. Acta 15, 109-124.

Pano, N., 1984. Hidrologjia e Shqiperise (Tirana, Albania: 1st Hidrometeorologjik, Akademia e Shkencave e repste Shqiperise).

Parker, J.G., 1983. A comparison of methods used for the measurement of organic matter in marine sediment. Chem. Ecol. 1, 201210.

Patrício, J., Ulanowicz, R., Pardal, M.A., Marques, J.C., 2004 Ascendency as an ecological indicator: a case study on estuarine pulse eutrophication. Estuarine Coastal Shelf Sci. 60, 23-35.

Peja, N., Vaso, A., Miho, A., Rakaj, N., Crivelli, A.J., 1996. Characteristics of Albanian lagoons and their fisheries. Fish. Res. 27, 215-225.

Pérez-España, H., Arreguín-Sánchez, F., 1999a. A measure of ecosystem maturity. Ecol. Model. 119 (1), 79-85.

Pérez-España, H., Arreguín-Sánchez, F., 1999b. Complexity related to behavior of stability in modeled coastal zone ecosystems. Aquat. Ecosyst. Health Manage. 2, 129-135.

Pérez-España, H., Arreguín-Sánchez, F., 2001. An inverse relationship between stability and maturity in models of aquatic ecosystems. Ecol. Model. 145 (2-3), 189-196.

Plante-Cuny, M.R., 1974. Evaluation par spectrophotomètrie des teneurs en chlorophyll- $a$ functonelle et en phaeopigments des substrats meubles marins. O.R.S.T.O.M. Nosy-Bé.

Romeyn, K., Bowman, L.A., 1983. Food selection and consumption by estuarine nematodes. Hydrobiol. Bull. 17 (2), 103-109.

Rybarczyk, H., Elkaim, B., Ochs, L., Loquet, N., 2003. Analysis of the trophic network of a macrotidal ecosystem: the Bay of
Somme (Eastern Channel). Estuarine Coastal Shelf Sci. 58 (3), 405-421.

Salas, F., Marcos, C., Pérez-Ruzafa, A., Marques, J.C., 2005. Application of the Exergy Index as ecological indicator along an organic enrichment gradient in the Mar Menor Lagoon (south-eastern Spain). Energy 30, 2005-2522.

Salomonsen, J., 1992. Examination of properties of exergy, power and ascendency along a eutrophication gradient. Ecol. Model. $62,171-181$.

Ulanowicz, R.E., 1986. Growth and Development: Ecosystems Phenomenology. Springer-Verlag, New York, 203 pp.

Ulanowicz, R.E., 2000. Ascendency: a measure of ecosystem performance. In: Jorgensen, S.E., Muller, F. (Eds.), Handbook of Ecosystem Theories and Management. Lewis Publishers, Boca Raton, pp. 303-315.

Ulanowicz, R.E., Abarca-Arenas, L.G., 1997. An informational synthesis of ecosystem structure and function. Ecol. Model. 95, 1-10.

Vezzulli, L., Chelossi, E., Riccardi, G., Fabiano, M., 2002. Bacterial community structure and activity in fish farm sediments of the Ligurian Sea (western Mediterranean). Aquacult. Int. 10 (2), 123-141.

Warwick, R.M., Price, R., 1979. Ecological and metabolic studies on free-living nematodes from an estuarine mud-flat. Estuarine Coastal Mar. Sci. 9, 257-271.

Wieser, W., 1960. Benthic studies in Buzzard Bay. II. The meiofauna. Limnol. Oceanogr. 5, 121-137.

Xu, Fu-Liu, Jørgensen, S.E., Shu, Tao, Ben-Gang, Li, 1999. Modeling the effects of ecological engineering on ecosystem health of a shallow eutrophic Chinese lake (Lake Chao). Ecol. Model. 117, 239-260.

Zavatarelli, M., Raicich, F., Bregant, D., Russo, A., Artegiani, A., 1998. Climatological biogeochemical characteristics of the Adriatic Sea. J. Mar. Syst. 18 (1-3), 227-263.

Zore, M., 1956. On gradient currents in the Adriatic Sea. Acta Adriatica 8 (6), 1-38. 